Subscriber access provided by Caltech Library

\title{
Letter
}

\section{Decoupling H2(g) and O2(g) Production in Water Splitting by a Solar-Driven V3+/2+(aq,H2SO4)|KOH(aq) Cell}

Alec Ho, Xinghao Zhou, Lihao Han, lan Sullivan, Christoph Karp, Nathan Lewis, and Chengxiang Xiang ACS Energy Lett., Just Accepted Manuscript • DOI: 10.1021/acsenergylett.9b00278 • Publication Date (Web): 21 Mar 2019 Downloaded from http://pubs.acs.org on March 21, 2019

\section{Just Accepted}

"Just Accepted" manuscripts have been peer-reviewed and accepted for publication. They are posted online prior to technical editing, formatting for publication and author proofing. The American Chemical Society provides "Just Accepted" as a service to the research community to expedite the dissemination of scientific material as soon as possible after acceptance. "Just Accepted" manuscripts appear in full in PDF format accompanied by an HTML abstract. "Just Accepted" manuscripts have been fully peer reviewed, but should not be considered the official version of record. They are citable by the Digital Object Identifier (DOI®). "Just Accepted" is an optional service offered to authors. Therefore, the "Just Accepted" Web site may not include all articles that will be published in the journal. After a manuscript is technically edited and formatted, it will be removed from the "Just Accepted" Web site and published as an ASAP article. Note that technical editing may introduce minor changes to the manuscript text and/or graphics which could affect content, and all legal disclaimers and ethical guidelines that apply to the journal pertain. ACS cannot be held responsible for errors or consequences arising from the use of information contained in these "Just Accepted" manuscripts. 
Decoupling $\mathrm{H}_{2}(\mathrm{~g})$ and $\mathrm{O}_{2}(\mathrm{~g})$ Production in Water Splitting by a Solar-Driven $\mathrm{V}^{3+/ 2+}\left(\mathrm{aq}, \mathrm{H}_{2} \mathrm{SO}_{4}\right) \mid \mathrm{KOH}(\mathrm{aq})$ Cell

\author{
Alec Ho ${ }^{1}$, Xinghao Zhou ${ }^{2}$, Lihao Han ${ }^{1}$, Ian Sullivan ${ }^{1}$, Christoph Karp ${ }^{1}$, Nathan S. Lewis ${ }^{1,3,4 *}$ \\ Chengxiang Xiang ${ }^{1 *}$
}

${ }^{1}$ Division of Chemistry and Chemical Engineering, California Institute of Technology, Pasadena, CA 91125, USA

${ }^{2}$ Division of Engineering and Applied Science, Department of Applied Physics and Materials Science, California Institute of Technology, Pasadena, CA 91125, USA

${ }^{3}$ Beckman Institute Molecular Materials Research Center, California Institute of Technology, Pasadena, CA 91125, USA

${ }^{4}$ Kavli Nanoscience Institute, California Institute of Technology, Pasadena, CA 91125, USA

*To whom correspondence should be addressed: nslewis@caltech.edu, cxx@caltech.edu 


\begin{abstract}
A solar-driven $\mathrm{V}^{3+/ 2+}\left(\mathrm{aq}, \mathrm{H}_{2} \mathrm{SO}_{4}\right) \mid \mathrm{KOH}(\mathrm{aq})$ cell, consisting of a carbon-cloth cathode in $2.0 \mathrm{M}$ $\mathrm{H}_{2} \mathrm{SO}_{4}(\mathrm{aq})$ with $0.36 \mathrm{M} \mathrm{V}_{2}\left(\mathrm{SO}_{4}\right)_{3}(\mathrm{pH}=-0.16)$, a Ni mesh anode in $2.5 \mathrm{M} \mathrm{KOH}(\mathrm{aq})(\mathrm{pH}=14.21)$ for the oxygen-evolution reaction (OER), and a bipolar membrane that sustained the $\mathrm{pH}$ differentials between the catholyte and anolyte, enabled water splitting with spatial and temporal decoupling of the hydrogen-evolution reaction (HER) from the OER and produced $\mathrm{H}_{2}(\mathrm{~g})$ locally under pressure upon demand. Over a range of potentials and charging depths, $\mathrm{V}^{3+}$ was selectively reduced with $>99.8 \%$ Faraday efficiency $(\mathrm{FE}) . \quad$ The $\mathrm{V}^{2+}$ species produced in the catholyte was then passed subsequently on demand over a $\mathrm{MoC}_{\mathrm{x}}$-based HER catalyst to produce $\mathrm{H}_{2}(\mathrm{~g})$ and regenerate $\mathrm{V}^{3+}$ for subsequent reduction. Under a base hydrogen pressure of $1 \mathrm{~atm}, 10 \mathrm{~atm}$ and $100 \mathrm{~atm}$, the discharge efficiency of the $\mathrm{V}^{3+}$ to hydrogen was $83 \%, 65.2 \%$ and $59.8 \%$, respectively. In conjunction with a solar tracker and a photovoltaic device, the $\mathrm{V}^{3+/ 2+}\left(\mathrm{aq}, \mathrm{H}_{2} \mathrm{SO}_{4}\right) \mid \mathrm{KOH}(\mathrm{aq})$ cell was charged outdoors under sunlight and discharged at night with a daily averaged diurnal solarto-hydrogen (STH) energy conversion efficiency of 3.7\% and a STH conversion efficiency of 5.8\% during daylight operation.
\end{abstract}




\section{TOC GRAPHICS}

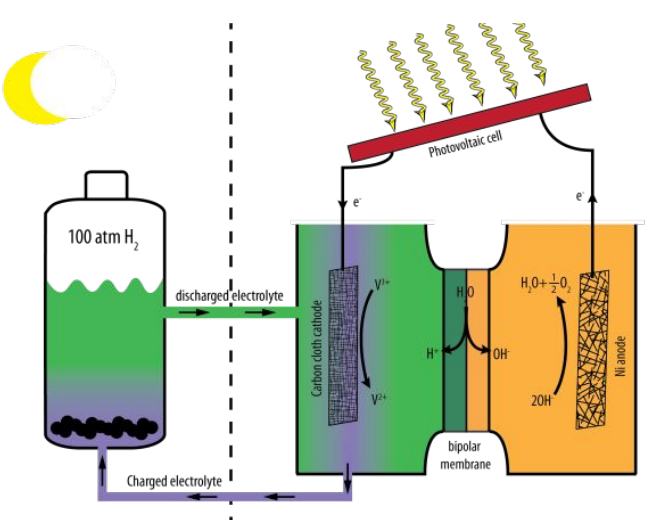


In a solar-driven water-splitting electrochemical cell, the hydrogen-evolution reaction (HER) occurs at the cathode while the oxygen-evolution reaction (OER) occurs at the anode:

HER in acidic solution: $\left.\quad 2 \mathrm{H}^{+}+2 \mathrm{e}^{-} \rightarrow \mathrm{H}_{2} \quad\left(E^{\circ}=-244 \mathrm{mV} \text { vs. SCE}\right)^{1}\right)$

HER in alkaline solution: $2 \mathrm{H}_{2} \mathrm{O}+2 \mathrm{e}^{-} \rightarrow \mathrm{H}_{2}+\mathrm{OH}^{-} \quad\left(E^{\circ}=-1074 \mathrm{mV}\right.$ vs. SCE $\left.\mathrm{SC}^{1}\right)$

OER in acidic solution: $\quad 2 \mathrm{H}_{2} \mathrm{O} \rightarrow \mathrm{O}_{2}+4 \mathrm{H}^{+}+4 \mathrm{e}^{-} \quad\left(E^{\circ}=986 \mathrm{mV}\right.$ vs. $\left.\mathrm{SCE}^{1}\right)$

OER in alkaline solution: $\quad 4 \mathrm{OH}^{-} \rightarrow \mathrm{O}_{2}+2 \mathrm{H}_{2} \mathrm{O}+4 \mathrm{e}^{-} \quad\left(E^{\circ}=156 \mathrm{mV} v\right.$ s. $\left.\mathrm{SCE}^{1}\right)$

where SCE is the standard calomel electrode in saturated $\mathrm{KCl}$. In a phototelectrochemical (PEC) cell, reaction (1) and reaction (2) are tightly coupled, and to insure charge neutrality, must proceed at the same rate. ${ }^{2-5}$ Hence, most solar-driven water-splitting cells, operated either under conventional single-electrolyte conditions, ${ }^{5-6}$ or in electrolytes that have sustained $\mathrm{pH}$ differentials between the catholyte and anolyte, ${ }^{3-4}$ generate $\mathrm{H}_{2}(\mathrm{~g})$ and $\mathrm{O}_{2}(\mathrm{~g})$ simultaneously in the cell, so that whenever one oxygen molecule is produced at the anode, two hydrogen molecules are produced at the cathode. $\mathrm{H}_{2}(\mathrm{~g}) / \mathrm{O}_{2}(\mathrm{~g})$ mixtures have a flammability limit of 4 vol.\% and an explosive limit of 15 vol. $\%,{ }^{7}$ so, for safety purposes, membrane separators such as a cation-exchange membrane (CEM), e.g., Nafion, an anion-exchange membrane (AEM), e.g., Selemion, or a bipolar membrane (BPM), e.g., Fumasep, are often used to support ionic transport and prevent gaseous-product crossover..$^{2-3}$ Membrane-free devices lack a robust mechanism to prevent product-gas crossover, and in some measurements, up to $40 \%$ of $\mathrm{H}_{2}$ is present in the $\mathrm{O}_{2}$-containing anolyte chamber ${ }^{8}$ but in some cases strategies have been developed to separate the products under 1 atm of pressure with low crossover rates. ${ }^{9-10}$ The membrane separator also facilitates the production of $\mathrm{H}_{2}(\mathrm{~g})$ under pressure by electrochemical processes..$^{11-12}$ 
Membrane separators provide an effective method to minimize product crossover, but mechanical failures and pinhole formation in the membrane introduce safety concerns. ${ }^{13-14}$ Additionally, such an approach necessitates a balance-of-systems for collection of the evolved $\mathrm{H}_{2}(\mathrm{~g})$ over large areas as well as pressure management technologies associated with accommodating the time-varying instantaneous intensity of sunlight striking the system at different spatial locations. ${ }^{2-3,6}$ An approach that enabled the separate generation of hydrogen and oxygen in space and time would thus entail several advantages, including mitigating the concern related to production of potentially flammable or explosive gas mixtures. In such an approach, the hydrogen generation rate could also beneficially be decoupled from, and thus could substantially exceed, the rate of generation of energetic electrons and holes in the illuminated light absorbers. Furthermore, the $\mathrm{H}_{2}$ could be formed upon demand under pressure at a specific desired location. A benign aqueous solution could constitute the redox catholyte material collected over the large solar-illuminated area and serve as the collected energy carrier, with the $\mathrm{O}_{2}(\mathrm{~g})$ produced in place and vented to the atmosphere without the presence of $\mathrm{H}_{2}(\mathrm{~g})$ at that location.

Two general strategies have been used to decouple the HER and OER electrochemically and/or photoelectrochemically. The first strategy involves a two-step electrolysis, in which the watersplitting reaction is effected in two physically distinct, separate electrochemical cells, using redox species or redox electrodes such as $\mathrm{NiOOH}$ electrodes, ${ }^{15-16}$ a polytriphenylamine-based battery electrode, ${ }^{17}$ or molecular electron-coupled-proton buffers. ${ }^{18-19}$ The second strategy to decouple the 
generation of hydrogen and oxygen involves a (photo-)electrochemical process in conjunction with a subsequent chemical process, using for example silicotungstic acid, ${ }^{20}$ vanadium or cerium redox couples $^{21}$ as electrochemical mediators to couple two electrochemical processes and allow completion of a sustainable, complete water-splitting process.

Herein, we demonstrate such a spatially and temporally decoupled approach to solar-driven electrochemical water-splitting, in which the electrons and protons generated during the OER are used to charge an aqueous $\mathrm{V}^{3+/ 2+}(\mathrm{aq})$ solution in $2.0 \mathrm{M}$ sulfuric acid $(\mathrm{pH}=-0.16)$ (Reaction 3), rather than being used directly to produce $\mathrm{H}_{2}(\mathrm{~g})$ at the cathode. The protons produced at the anode are transported to the catholyte and temporarily stored in the catholyte, which causes the decrease of the catholyte $\mathrm{pH}$ during the charging process.

$$
\mathrm{V}^{3+}+\mathrm{e}^{-} \rightarrow \mathrm{V}^{2+}\left(E^{\circ}=-0.499 \mathrm{~V} v s . \mathrm{SCE}\right)
$$

To produce $\mathrm{H}_{2}(\mathrm{~g})$ from water, the catholyte that contains the $\mathrm{V}^{2+}$ is then exposed upon demand, if desired at a separate location and time, to a catalyst in the dark. During the chemical discharging process, the $\mathrm{pH}$ of the catholyte increases back to its initial value upon the release of hydrogen. In the demonstration system developed herein, the charged vanadium solution $\mathrm{V}^{2+}$ is specifically contacted with a $\mathrm{Mo}_{2} \mathrm{C}$ catalyst, resulting in the production of $\mathrm{H}_{2}(\mathrm{~g})$ and $\mathrm{V}^{3+}$ (Reaction 4).

$$
2 \mathrm{H}^{+}+2 \mathrm{~V}^{2+} \stackrel{M o_{2} C}{\longrightarrow} \mathrm{H}_{2}+2 \mathrm{~V}^{3+}
$$

The full cell, and thus the overall water-splitting process, is completed with the evolution of $\mathrm{O}_{2}(\mathrm{~g})$ from water at the anode, as per equation (2a) or (2b). 
The $\mathrm{V}^{3+/ 2+}$ redox couple is however only soluble in acidic conditions, in which a stable, active, earth-abundant OER catalyst has yet to be discovered. ${ }^{22-23}$ A range of OER catalysts composed of binary, ternary or quaternary metal oxides exhibit low overpotentials and high stabilities in alkaline conditions. ${ }^{24-27}$ To simultaneously accommodate the optimal $\mathrm{pH}$ conditions for the OER and vanadium redox reactions, a bipolar membrane has thus been used in the demonstration system discussed herein, to sustain the $\mathrm{pH}$ differential between the cathode and the anode chamber under steady-state operation in the cell as well as to enable the use of earth-abundant electrocatalysts in a system that produces $\mathrm{H}_{2}(\mathrm{~g})$ locally under pressure and upon demand. Fig.S1 shows a schematic illustration of the full process flow.

Fig. 1 shows a schematic illustration of the solar-driven $\mathrm{V}^{3+/ 2+}\left(\mathrm{aq}, \mathrm{H}_{2} \mathrm{SO}_{4}\right) \mid \mathrm{KOH}(\mathrm{aq})$ system, which for proof-of-concept purposes consisted of a series connection between a photovoltaic module and an electrochemical cell. The $16.0 \%$ efficient polycrystalline Si photovoltaic module produced the photovoltage and photocurrent necessary to drive the electrochemical reactions, although an analogous process could occur in an integrated system that used instead a photoelectrode either as the anode, cathode, or both. ${ }^{28-30}$ For example, in conjunction with appropriately selected photoanodes, $\mathrm{p}$-InP and $\mathrm{p}$-Si could be used in an integrated system, since both materials provide stable photocathodes in contact with $\mathrm{V}^{3+/ 2+}(\mathrm{aq})-\mathrm{HCl}(\mathrm{aq})$ with $\mathrm{p}$-InP exhibiting $>11 \%$ efficiency under such conditions. ${ }^{31}$ A carbon cloth electrode effected the reduction of vanadium in $2.0 \mathrm{M}$ $\mathrm{H}_{2} \mathrm{SO}_{4}(\mathrm{pH}=-0.16)$, with an initial $\left[\mathrm{V}^{3+}\right]=0.36 \mathrm{M}$; a Ni mesh electrode performed the OER in 2.5 $\mathrm{M} \mathrm{KOH}(\mathrm{pH}=14.21)$; and a bipolar membrane sustained the $\mathrm{pH}$ differentials and provided protons 
and hydroxide ions to the catholyte and anolyte, respectively.

The electrochemical behaviors of the cathode, anode and the bipolar membrane have been evaluated separately (Fig. 2). Fig. 2a shows the liner sweep voltammetry, at a scan rate of $40 \mathrm{mV}$ $\mathrm{s}^{-1}$, of a Ni mesh electrode in $2.5 \mathrm{M} \mathrm{KOH}(\mathrm{aq})(\mathrm{pH}=14.21)(\mathrm{red})$ and of a Pt foil electrode in 1.0 $\mathrm{M} \mathrm{H}_{2} \mathrm{SO}_{4}(\mathrm{aq})$ (blue). Under these conditions, an overpotential of $379 \mathrm{mV}$, i.e. a potential of 539 $\mathrm{mV} v s$. SCE was required for the Ni mesh to drive the OER at an anodic geometric current density of $10 \mathrm{~mA} \mathrm{~cm}^{-2}$. The relatively low current density, $10 \mathrm{~mA} \mathrm{~cm}$, was chosen for evaluating the catalyst and cell performance due to the relatively low photon flux from sunlight for the potential usage of this proof-of-concept device in a distributed system. Fig. $2 \mathrm{~b}$ shows the voltammetry, at a scan rate of $40 \mathrm{mV} \mathrm{s}^{-1}$, of a carbon cloth electrode in a $2.0 \mathrm{M} \mathrm{H}_{2} \mathrm{SO}_{4}(\mathrm{aq})$ with (green) and without $0.36 \mathrm{M} \mathrm{V}_{2}\left(\mathrm{SO}_{4}\right)_{3}$ (black). A potential of $-765 \mathrm{mV}$ s. SCE, i.e. an overpotential of $-266 \mathrm{mV}$ relative to $E^{\mathrm{o}^{\prime}}\left(\mathrm{V}^{3+/ 2+}\right)$, was required to drive the $\mathrm{V}^{3+}$ reduction at a cathodic geometric current density of $10 \mathrm{~mA} \mathrm{~cm}^{-2}$. In contrast, at the same current density in the pure $2.0 \mathrm{M} \mathrm{H}_{2} \mathrm{SO}_{4}(\mathrm{aq})$ solution, a potential of $-858 \mathrm{mV} v$ s. SCE, i.e. an overpotential of $-614 \mathrm{mV}$, was required to drive the HER. During the vanadium redox charging process, HER is a parasitic side reaction, which is suppressed due to the slow kinetics for the HER at carbon cloth electrodes.

The polarization behaviors of the bipolar membrane that sustained the $\mathrm{pH}$ differentials between the catholyte and anolyte with or without the vanadium redox couples were measured absence of, and then in the presence of, the vanadium redox couples. Fig. $2 \mathrm{c}$ shows the voltage drop measured 
with a four-point configuration across the bipolar membrane, as a function of the current density normalized to the area of the bipolar membrane. The grey polarization curve represents the electrolyte combination of $\mathrm{KOH}(\mathrm{aq})(\mathrm{pH}=14.21)$ and $2.0 \mathrm{M} \mathrm{H}_{2} \mathrm{SO}_{4}(\mathrm{aq})(\mathrm{pH}=-0.16)$ without the vanadium redox species. A slight decrease in the voltage loss was observed when $0.36 \mathrm{M} \mathrm{V}_{2}\left(\mathrm{SO}_{4}\right)$ was added to the catholyte (black polarization curve, Fig. 2c), likely due to the increased the conductivity of the solution due to the presence of additional electrolyte. At open-circuit, the

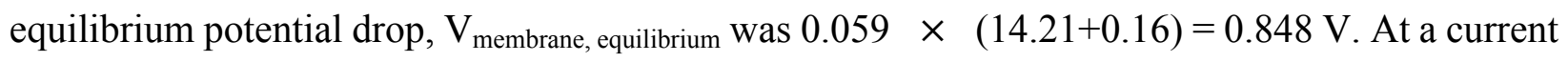
density of $10 \mathrm{~mA} \mathrm{~cm}{ }^{-2}$, the potential difference across the bipolar membrane was $0.866 \mathrm{~V}$ in the presence of $\mathrm{V}^{3+/ 2+}$. The bipolar membrane voltage loss at $10 \mathrm{~mA} \mathrm{~cm}-2$ was therefore $\mathrm{V}_{\text {membrane, loss }}$ $=\mathrm{V}_{\text {membrane, total }}-\mathrm{V}_{\text {membrane, equilibrium }}=0.866 \mathrm{~V}-0.848 \mathrm{~V}=0.018 \mathrm{~V}$. The observed current voltage characteristic of the bipolar membrane at two extreme $\mathrm{pH}$ values is in agreement with prior reports, ${ }^{32-33}$ and is substantially lower than voltage losses across bipolar membranes operated in near-neutral $\mathrm{pH}$ conditions. ${ }^{3,33-36}$ Table $\mathrm{S} 1$ summarized the voltage losses in the reported bipolar membrane systems. At two extreme $\mathrm{pHs}$, the minimal voltage loss across the bipolar membrane, ${ }^{33}$, 37 is consistent with the hypothesis that no additional Donnan potential drop is present across the membrane/electrolyte interface, and all the electric field drops primarily occur at the CEM and AEM interface. The voltage stability as well as the crossover properties of the bipolar membrane was also measured. Fig. $2 \mathrm{~d}$ shows the voltage measured across the bipolar membrane as a function of time, when the $0.36 \mathrm{M} \mathrm{V}_{2}\left(\mathrm{SO}_{4}\right)_{3}, 2.0 \mathrm{M} \mathrm{H}_{2} \mathrm{SO}_{4}(\mathrm{aq})(\mathrm{pH}=-0.16) /$ bipolar membrane $/ 2.5 \mathrm{M}$ $\mathrm{KOH}(\mathrm{aq})(\mathrm{pH}=14.21)$ cell was biased at a constant current density of $10 \mathrm{~mA} \mathrm{~cm}^{-2}$. These data indicated negligible degradation in the voltage across the bipolar membrane over the course of a 
200 h stability test. For $>200$ h, the bipolar membrane remained stable, and no precipitate was observed either in the bipolar membrane or in the anolyte. The geometric surface areas of the bipolar membrane, carbon cathode, and nickel mesh anode were all $6.0 \mathrm{~cm}^{2}$. To study the ion crossover behaviors, the concentrations of $\mathrm{V}^{3+/ 2+}$ in the anolyte before and after continuous operation at $10 \mathrm{~mA} \mathrm{~cm}^{-2}$ for $24 \mathrm{~h}$ were determined using inductively coupled plasma mass spectroscopy (ICP-MS, Table S2), and the concentrations of $\mathrm{K}^{+}$in the catholyte and $\mathrm{SO}_{4}{ }^{2-}$ in the anolyte were determined using ion chromatography (IC). Table 1 lists the transport current density corresponding to the leakage of $\mathrm{V}^{3+/ 2+}, \mathrm{K}^{+}$and $\mathrm{SO}_{4}{ }^{2-}$ across the membrane when the cell was operated at $10 \mathrm{~mA} \mathrm{~cm}^{-2}$. The membrane selectivity in the absence of and then in the presence of vanadium species, determined by the ratio of the proton-carried and hydroxide-carried portions of the total passed charges, $f_{\mathrm{H}^{+}}$and $f_{\mathrm{OH}^{-}}$, is also summarized in Table 1 . The $\mathrm{V}^{3+/ 2+}$ crossover current density was negligible partly due to the electric field lines during the cell operation repelling the positively charged vanadium redox species from entering the bipolar membrane and the anolyte. The presence of $\mathrm{V}^{3+/ 2+}$ also did not substantially affect membrane selectivity. Both the $f_{\mathrm{H}^{+}}$and $f_{\mathrm{OH}^{-}}$ values exceeded $92 \%$ at an operating current density of $10 \mathrm{~mA} \mathrm{~cm}^{-2}$, in accord with prior results. ${ }^{3}$

Table 1. Ion crossover rates for the bipolar membrane in the absence of and then in the presence of vanadium ions

\begin{tabular}{|l|l|l|l|l|l|}
\hline$J_{\text {Membrane }}=10 \mathrm{~mA} \mathrm{~cm}^{-2}$ & $J_{\mathrm{V}^{3+/ 2+}}$ & $J_{\mathrm{K}^{+}}$ & $J_{\mathrm{SO}_{4}{ }^{2-}}$ & $f_{\mathrm{H}^{+}}$ & $f_{\mathrm{OH}^{-}}$ \\
\hline
\end{tabular}




\begin{tabular}{|c|c|c|c|c|c|}
\hline With $\mathrm{V}^{3+/ 2+}$ & $0.226 \mu \mathrm{A} \mathrm{cm}^{-2}$ & $787 \mu \mathrm{A} \mathrm{cm}^{-2}$ & $54 \mu \mathrm{A} \mathrm{cm}^{-2}$ & $92.1 \%$ & $99.5 \%$ \\
\hline Without $\mathrm{V}^{3+/ 2+}$ & N.A. & $606 \mu \mathrm{A} \mathrm{cm}^{-2}$ & $184 \mu \mathrm{A} \mathrm{cm}^{-2}$ & $93.9 \%$ & $98.2 \%$ \\
\hline
\end{tabular}

The electrochemical charging and discharging behaviors of the carbon cloth electrode in $\mathrm{V}^{3+/ 2+}$, 2.0 $\mathrm{M} \mathrm{H}_{2} \mathrm{SO}_{4}(\mathrm{aq})$ were then investigated. Fig. 3a shows the experimental (red) and theoretical (blue) decay of the current density with respect to charge passed into a $0.36 \mathrm{M} \mathrm{V}_{2}\left(\mathrm{SO}_{4}\right)_{3}, 2.0 \mathrm{M} \mathrm{H}_{2} \mathrm{SO}_{4}$ solution. To obtain the current density ascribable to $\mathrm{V}^{3+}$ reduction (Fig. 3a, red), the current density that effected $\mathrm{H}_{2}(\mathrm{~g})$ production (black) was subtracted from the overall current density, with the average $\mathrm{H}_{2}(\mathrm{~g})$-related current density over $30 \mathrm{~min}$ intervals calculated by measurement of the amount of $\mathrm{H}_{2}(\mathrm{~g})$ collected with respect to charge passed. The decrease in current density as a function of charge passed followed the trend expected from the Nernst relation (Equation 5), where $k$ is Boltzmann's constant, $T$ is the absolute temperature, $e$ is the unsigned charge on an electron, $E$ is the Nernstian cell potential, $E^{\circ}$ is the formal potential, [Red] is the concentration of reduced species and $[\mathrm{Ox}]$ is the concentration of oxidized species.

$$
E=E^{O^{\prime}}-\frac{k T}{q} \ln \frac{[R e d]}{[O x]}
$$

The initial rapid decay of the current density was due to the rapid change of $E\left(\mathrm{~V}^{3+/ 2+}\right)$ (Equation 2). As $\left[\mathrm{V}^{3+}\right]$ decreased and $\left[\mathrm{V}^{2+}\right]$ increased linearly as a function of the charge passed, the Nernstian cell potential shifted logarithmically to more negative values, consistent with the observed decreases in the charging current (Fig. 3a). The $\mathrm{pH}$ of the catholyte, an aqueous $\mathrm{V}^{3+/ 2+}$ (aq) solution in 2.0 M sulfuric acid, of the hybrid solar-driven water-splitting system decreased during the charging process and increased back to its initial value during the discharging process. The change 
of the $\mathrm{pH}$ in the reported system is small (from -0.16 to -0.30 ) due to the large concentration differential between the redox species and the sulfuric acid, and consequently the $\mathrm{pH}$ change had minimal effects on the catalytic activities of the redox species or on the efficiency of the device.

Fig. $3 b$ shows the collected $\mathrm{H}_{2}(\mathrm{~g})$ as a function of the charge passed for the carbon cloth cathode at $-730 \mathrm{mV}$ (purple), $-830 \mathrm{mV}$ (green), and $-1000 \mathrm{mV}$ (blue) vs. SCE, respectively, in $0.36 \mathrm{M}$ $\mathrm{V}_{2}\left(\mathrm{SO}_{4}\right)_{3}, 2.0 \mathrm{M} \mathrm{H}_{2} \mathrm{SO}_{4}(\mathrm{aq})$. Before the charging capacity of the electrolyte was reached at each different potential, negligible $\mathrm{H}_{2}(\mathrm{~g})$ was produced during charging of the $50.0 \mathrm{~mL} \mathrm{~V}^{3+/ 2+}(\mathrm{aq})$ solution. In contrast, as expected, a linear increase of the collected $\mathrm{H}_{2}(\mathrm{~g})$ production (red) as a function of the charge passed was observed for the same carbon cloth electrode in the blank $2.0 \mathrm{M}$ $\mathrm{H}_{2} \mathrm{SO}_{4}$ (red) (dotted black line). For the carbon cloth electrode at $-830 \mathrm{mV}$ or at $-1000 \mathrm{mV} v \mathrm{~s}$. SCE, after the vanadium electrolyte reached its charging capacity, a rapid switch to $\mathrm{H}_{2}(\mathrm{~g})$ production was observed, with a rate of $\mathrm{H}_{2}(\mathrm{~g})$ generation matching the theoretical value. When the carbon cloth electrode was poised at $-730 \mathrm{mV} v s$. SCE, an increase in the rate of $\mathrm{H}_{2}(\mathrm{~g})$ production began at $\sim 83 \%$ of the $\mathrm{V}^{3+/ 2+}$ charging capacity. The operating current density decreased substantially, to $\sim 0 \mathrm{~mA} \mathrm{~cm}{ }^{-2}$, for the low-overpotential condition $(-730 \mathrm{mV} v s . \mathrm{SCE})$, whereas before reaching its charging capacity (see Fig. S2), the operating cathodic current density remained above $\sim 0.8 \mathrm{~mA}$ $\mathrm{cm}^{-2}$ and $\sim 2.5 \mathrm{~mA} \mathrm{~cm}^{-2}$ for the high-overpotential conditions, $-830 \mathrm{mV}$ and $-1000 \mathrm{mV}$, respectively. Hence, during charging, the shifts in the equilibrium potential for the vanadium electrolyte resulted in the decrease in operating current density (Fig. 3a), and decreased the selectivity towards vanadium reduction. To achieve near-unity Faraday efficiency (FE) for vanadium reduction, an 
overpotential of $331 \mathrm{mV}$, or a potential of $-830 \mathrm{mV} v s$. SCE, was required during the reaction.

The collected $\mathrm{H}_{2}(\mathrm{~g})$ as a function of the charge passed for the carbon cloth electrode at $-830 \mathrm{mV}$ vs. SCE, at three different charging depths, is presented in Fig. 3c. The carbon cloth electrode exhibited near-unity $F E$ for vanadium reduction at charge capacities of $27 \%$ (orange), 55\% (blue), and $96 \%$ (black), as well as past $100 \%$ (green). The highly selective reduction of $\mathrm{V}^{3+}$ to $\mathrm{V}^{2+}$, relative to $\mathrm{H}_{2}(\mathrm{~g})$ formation, resulted from the competition between the thermodynamic potential of the HER and the kinetic overpotential for vanadium reduction. Although at $\mathrm{pH}=-0.16, E^{\mathrm{o}}$ $\left(\mathrm{H}^{+} / \mathrm{H}_{2}\right)$ is $255 \mathrm{mV}>E^{\mathrm{o}^{\prime}}\left(\mathrm{V}^{3+/ 2+}\right)$, carbon cloth is a poor electrocatalyst for the HER, leading to near-unity $F E$ for the vanadium reduction even at potentials substantially more negative than $E^{\mathrm{o}}$ $\left(\mathrm{H}^{+} / \mathrm{H}_{2}\right)$. In addition, the HER was suppressed substantially when the electrode was biased at the same potential $(-830 \mathrm{mV} v s$. SCE) in the electrolyte with the presence of vanadium redox couples (Fig. 2b). From the voltammetric behavior (the black and the green curve in Fig. 2b) of the electrodes, the differential current densities at $-830 \mathrm{mV}$ vs. SCE suggest only $\sim 40 \% \mathrm{FE}$ for vanadium reduction, however, near-unity FE was observed at various charging conditions. The absorption of vanadium species at the carbon cloth electrode is likely to play a role in suppressing the HER. During the entire charging process, the expected $\mathrm{pH}$ changes were observed in the catholyte. The stored reducing equivalents in $\mathrm{V}^{2+}$ can however be rapidly and efficiently converted into $\mathrm{H}_{2}(\mathrm{~g})$ by the $\mathrm{Mo}_{2} \mathrm{C}$ catalyst (see Fig. $\mathrm{S} 4$ for experimental setup). Accordingly, $\mathrm{H}_{2}(\mathrm{~g})$ production efficiencies (based on the total amount of charge passed) of $87 \%, 87 \%$ and $83 \%$ were observed for vanadium solutions that were charged to $27 \%, 55 \%$ and $96 \%$ of their charging 
capacity, respectively (Fig. $3 \mathrm{~d}$ ), when the produced $\mathrm{H}_{2}(\mathrm{~g})$ was vented to the atmosphere. $\mathrm{The}_{2}(\mathrm{~g})$ production efficiencies were defined by the following equation:

$$
\eta_{H 2}=\frac{n F\left(V_{\text {collected_H2 } \left./ V_{\mathrm{m}}\right)}\right.}{Q}
$$

where $n$ is the number of electrons, $F$ is Faraday's constant, $V_{\text {collected_H2 }}$ is the volume of the collected $\mathrm{H}_{2}(\mathrm{~mL}), V_{\mathrm{m}}$ is the molar volume of gas and $Q$ is the total quantity of electric charge passed during the charging process. The $\mathrm{Mo}_{2} \mathrm{C}$ catalyst can be readily filtered through the discharged electrolyte, facilitating catalyst recycling and reuse.

Discharging of the $\mathrm{V}^{2+}$ electrolyte was also performed under elevated pressures in a pressurized stainless-steel apparatus (Fig. S5 and Fig. S6). The apparatus consisted of $10.4 \mathrm{~mL}$ of headspace and $25.0 \mathrm{~mL}$ of fully charged $\mathrm{V}^{2+}$ electrolyte, as well as the $\mathrm{Mo}_{2} \mathrm{C}$ catalyst. The pressure of the headspace was equilibrated at $10.0 \mathrm{~atm}$ or at $100.0 \mathrm{~atm}$ with hydrogen gas. Upon contact of the charged $\mathrm{V}^{3+/ 2+}$ solution with the $\mathrm{Mo}_{2} \mathrm{C}$ catalyst, the pressure of the headspace increased rapidly, due to the production of $\mathrm{H}_{2}(\mathrm{~g})$. At 10.0 atm and 100.0 atm base pressure, the discharge of the $\mathrm{V}^{2+}$ electrolyte increased the pressure of the headspace by $6.65 \mathrm{~atm}$ and 5.97 atm, respectively, corresponding to $\mathrm{H}_{2}(\mathrm{~g})$ production efficiencies of $65.2 \%$ and $59.8 \%$, respectively.

The electricity-to-fuel conversion efficiency of the bipolar membrane-based hybrid system (Table 2, System C), in which the cathode operated in an acidic solution for vanadium reduction and the anode effected the OER in an alkaline electrolyte, was compared to the behavior of two previously reported systems (Table 2, System A or System B) for hydrogen production at $1 \mathrm{~atm}$. The 
electricity-to-fuel conversion efficiency of those systems was defined by the following equation:

$$
\eta_{\text {electricity }- \text { to }- \text { fuel }}=\frac{V_{\text {thermodynamic }}}{V_{\text {operating }}}
$$

System $\mathrm{A}$ is a conventional, direct water-splitting reactor in $1.0 \mathrm{M} \mathrm{H}_{2} \mathrm{SO}_{4}(\mathrm{aq})$, in which the $\mathrm{Pt}$ cathode and the $\mathrm{IrO}_{\mathrm{x}}$ anode are separated by a Nafion membrane. System B consists of a previously reported indirect water-splitting reactor in which the carbon cloth cathode for vanadium reduction and a Pt anode for Ce oxidation (Reaction 8) are separated by a Nafion membrane, with the anolyte and catholyte both at the same $\mathrm{pH}$, i.e. $1.0 \mathrm{M} \mathrm{H}_{2} \mathrm{SO}_{4}(\mathrm{aq}) .{ }^{21}$

$$
\mathrm{Ce}^{3+} \rightarrow \mathrm{Ce}^{4+}+\mathrm{e}^{-}\left(E^{\circ}=1.72 \mathrm{~V} v s . \mathrm{SCE}\right)
$$

In system $B$, the reduced vanadium electrolyte and the oxidized cerium electrolyte can be discharged separately to produce $\mathrm{H}_{2}(\mathrm{~g})$ (Reaction 4) and $\mathrm{O}_{2}(\mathrm{~g})$ (Reaction 9), respectively. ${ }^{21}$

$$
2 \mathrm{H}_{2} \mathrm{O}+4 \mathrm{Ce}^{4+\stackrel{R u O_{2}}{\longrightarrow}} \mathrm{O}_{2}+4 \mathrm{H}^{+}+4 \mathrm{Ce}^{3+}
$$

Table 2 presents the total voltage required for operation under thermodynamic limit for each of the three systems under consideration. The value of $E^{\circ}\left(\mathrm{V}^{3+/ 2+}\right)$ is $255 \mathrm{mV}$ more negative than $E^{\circ}\left(\mathrm{H}^{+} / \mathrm{H}_{2}\right)$, whereas $E^{\circ}\left(\mathrm{Ce}^{4+/ 3+}\right)$ is $490 \mathrm{mV}$ more positive than $E^{\circ}\left(\mathrm{O}_{2} / \mathrm{H}_{2} \mathrm{O}\right)$. Hence, at the thermodynamic limit, the required voltage for System B is $745 \mathrm{mV}$ larger than for System A, and the required voltage for System C is $255 \mathrm{mV}$ more than for System A. Assuming that $\mathrm{H}_{2}(\mathrm{~g})$ under standard conditions is the final product for all three systems, the ideal electricity-to-hydrogen conversion efficiencies, for System B and System C are therefore 1.230 V/ $1.698 \mathrm{~V}=72 \%$, and $1.230 \mathrm{~V} / 1.488 \mathrm{~V}=83 \%$, respectively. 
To facilitate comparisons between the three systems operating under realistic conditions, Fig. 2 also displays the behavior of a state-of-the-art Pt electrode for the HER as well as for the oxidation of $\mathrm{Ce}^{3+}$ oxidation in acid. The state-of-the-art Pt electrode (grey curve in Fig. 2b) exhibited a small overpotential $(37 \mathrm{mV})$ at a current density of $-10 \mathrm{~mA} \mathrm{~cm}^{-2}$ for the HER. The larger overpotential for $\mathrm{V}^{3+}$ reduction at the carbon-cloth electrode $\left(266 \mathrm{mV}\right.$ at $-10 \mathrm{~mA} \mathrm{~cm} \mathrm{~cm}^{-2}$, see Table S3) relative to the state-of-the-art HER performance at Pt produces a loss in efficiency in this indirect solar-driven water-splitting system and is likely due to the electrolyte resistive loss in a large geometric area electrode $\left(6.0 \mathrm{~cm}^{2}\right)$ operating at high currents, which could be further minimized through cell engineering. To drive cerium oxidation (Reaction 5) at $10 \mathrm{~mA} \mathrm{~cm}^{-2}$ (blue curve in Fig. 2a) at Pt, a potential of $1684 \mathrm{mV} v s$. SCE, i.e. an overpotential of $244 \mathrm{mV}$, was required. These overpotentials (see Table S3) yield practical electricity-to-hydrogen conversion efficiencies for System B and System C of $52 \%$ and $54 \%$, respectively. In addition to the higher attainable electricity-to-fuel conversion efficiency, System $\mathrm{C}$ also mitigates the need for noble-metal catalysts, such as $\mathrm{RuO}_{2}$ in a heated environment, which also entails limited stability for oxygen generation from the $\mathrm{Ce}^{4+}$ solution. ${ }^{21}$ Note that these efficiency values include losses associated with a lack of equilibration of $\mathrm{H}_{2}$ under pressure with the charged vanadium solution, but neglect the generally small losses associated with energy required to circulate the electrolyte.

Table 2. Comparison of conversion efficiencies of three different systems 


\begin{tabular}{|c|c|c|c|}
\hline & System A & System B & System C \\
\hline Thermodynamic voltage & $1.230 \mathrm{~V}$ & $1.698 \mathrm{~V}$ & $1.488 \mathrm{~V}$ \\
\hline Ideal conversion efficiency & $100 \%$ & $72 \%$ & $83 \%$ \\
\hline Realistic conversion efficiency & $72 \%$ & $52 \%$ & $54 \%$ \\
\hline
\end{tabular}

System A: Pt/1.0 $\mathrm{M} \mathrm{H}_{2} \mathrm{SO}_{4} / \mathrm{Nafion}_{1} .0 \mathrm{M} \mathrm{H}_{2} \mathrm{SO}_{4} / \mathrm{IrO}_{\mathrm{x}}$ System B: Carbon cloth/2.0 $\mathrm{M} \mathrm{H}_{2} \mathrm{SO}_{4} 0.36 \mathrm{M} \mathrm{V}_{2}\left(\mathrm{SO}_{4}\right)_{3} / \mathrm{Nafion}_{1} .0 \mathrm{M} \mathrm{H}_{2} \mathrm{SO}_{4} 0.10 \mathrm{M} \mathrm{Ce}^{3+} / \mathrm{Pt}$ System C: Carbon cloth/2.0 $\mathrm{M} \mathrm{H}_{2} \mathrm{SO}_{4} 0.36 \mathrm{M} \mathrm{V}_{2}\left(\mathrm{SO}_{4}\right)_{3} / \mathrm{BPM} / 2.0 \mathrm{M} \mathrm{KOH} / \mathrm{Ni}$ mesh

This hybrid solar-driven water-splitting system represents a proof-of-concept demonstration of a strategy $\mathrm{y}^{20-21}$ for decoupling HER and OER in which a (photo-)electrochemical process is followed by a chemical process, separated in space and time, to produce hydrogen. In traditional PEC systems, generation of pressurized hydrogen over larges area can be challenging due to issues associated with light management, reactant/product flows, etc. This hybrid system also enables the (photo-)electrochemical pressurization of hydrogen, using the vanadium redox couple as a mediator to store pressurized hydrogen in a liquid electrolyte. A similar concept has been reported previously using a two-electron, two-proton mediator, silicotungstic acid, for hydrogen generation. ${ }^{18}$ In contrast, the hybrid system described herein additionally utilized a bipolar membrane to mitigate the use of precious materials, such as $\mathrm{Pt}$, $\mathrm{Ir}$ or $\mathrm{Ru}$, for the water-oxidation reaction. In a two-step electrolysis system, in which the water-splitting reaction is effected in two physically distinct, separate electrochemical cells using redox species or redox electrodes, ${ }^{14-15,17-}$ 
19 the hybrid approach demonstrated herein is likely to have lower capital costs because only one electrolysis unit, and associate balance of systems, is required.

To demonstrate the capability of this system to produce spatially and temporally separated streams of $\mathrm{O}_{2}(\mathrm{~g})$ and $\mathrm{H}_{2}(\mathrm{~g})$, the $\mathrm{V}^{3+/ 2+}\left(\mathrm{aq}, \mathrm{H}_{2} \mathrm{SO}_{4}\right) \mid \mathrm{KOH}(\mathrm{aq})$ cell with a $6.0 \mathrm{~cm}^{2}$ electrode area was connected in series with a $16 \%$ efficient, $13.1 \mathrm{~cm}^{2}$ polycrystalline photovoltaic module attached to a solar tracker, and the whole apparatus was tested outdoors (see Fig. S3 for picture of the outdoor setup). Fig. 4a shows the illumination intensity (blue) and system current (black) for operation during a day. For the first $\sim 4.5 \mathrm{~h}$, the photocurrent fluctuated around $73 \mathrm{~mA}$, while the illumination intensity fluctuated around $95 \mathrm{~mW} \mathrm{~cm}$. The fluctuations in the photocurrent matched corresponding fluctuations in illumination intensity that were produced by environmental factors. Between 14:17 and 15:47, a wind-blown tree caused extreme variability in the illumination intensity, decreasing it from 95 to $\sim 5$ to $\mathrm{mW} \mathrm{cm}^{-2}$, and consequently producing a reduction in the photocurrent from $69 \mathrm{~mA}$ to $5.0 \mathrm{~mA}$. Cloud-cover between 16:45 to 17:00 caused the illumination intensity to drop to $\sim 5 \mathrm{~mW} \mathrm{~cm}^{-2}$ and the photocurrent to drop to $\sim 5.0 \mathrm{~mA}$. After 17:17, a building blocked the photovoltaic module from illumination by direct sunlight, so the illumination intensity decreased to $<3 \mathrm{~mW} \mathrm{~cm}^{-2}$, causing the current to decrease to $<3.0 \mathrm{~mA}$. Fig. $4 \mathrm{~b}$ overlays the polarization behavior of the stand-alone $\mathrm{V}^{3+/ 2+}\left(\mathrm{aq}, \mathrm{H}_{2} \mathrm{SO}_{4}\right) \mid \mathrm{KOH}(\mathrm{aq})$ cell with the current density $v s$. voltage $(J-V)$ behavior of the photovoltaic module at various points in the day. As the $\mathrm{V}^{3+/ 2+}$ solution was charged during the outdoor measurements, the polarization data shifted to higher overpotentials and lower current densities, in accordance with the Nernst equation (Equation 5). 
Shifts in the $J-V$ and polarization behavior together caused the photocurrent to vary during operation. After charging to $85 \%$ capacity, the entire $50 \mathrm{~mL}$ of catholyte was discharged with $\mathrm{Mo}_{2} \mathrm{C}$, producing $\mathrm{H}_{2}(\mathrm{~g})$ at $80 \%$ overall faradaic efficiency based on the total charge passed. The discharged solution was then filtered with successively smaller filters, and the solution was reused in the system. After the reused solution was charged to $86 \%$ capacity, the whole solution was discharged, and produced $\mathrm{H}_{2}(\mathrm{~g})$ at $78 \%$ overall faradaic efficiency based on the total charge passed in the second $\mathrm{V}^{3+/ 2+}$ charging process. In this second charging step, the presence of $\mathrm{Mo}_{2} \mathrm{C}$ particles $<0.2 \mu \mathrm{m}$ in size catalyzed the parasitic HER side reaction during charging, leading to a small drop in efficiency in the reused catholyte. Increases in the catalyst size, or using an additional smaller filter, would likely be beneficial to recycling the system. Consistently, charging a fresh vanadium solution to $66 \%$ capacity yielded $\mathrm{H}_{2}(\mathrm{~g})$ at $84 \%$ overall faradaic efficiency based on the total charge passed in this first new charging cycle.

Two efficiency values, a diurnal averaged STH conversion efficiency, $\eta_{\text {diurnal }}$, and an average STH conversion efficiency during daylight operation, $\eta_{\text {operating, }}$ were used to evaluate the performance of the PV-coupled hybrid device. $\eta_{\text {diurnal }}$ was defined as $\frac{L^{2} H_{H_{2}} m_{H_{2}}}{\left(D N I_{\text {diurnal }}+D H I_{\text {dirunal }}\right) A_{P V}}$, and $\eta_{\text {operating }}$ was defined as $\frac{L V H_{H_{2}} m_{H_{2}}}{\left(D N I_{\text {operating }}+D H I_{\text {operating }}\right) A_{P V}}$, in which $L V H_{H_{2}}$ is the lower heating value of hydrogen, $m_{H_{2}}$ is the mass of hydrogen collected from the vanadium discharge reaction, $A_{P V}$ is the area of the photovoltaic module, $D N I_{\text {diurnal }}$ and $D N I_{\text {operating }}$ are the direct normal irradiance integrated over a diurnal cycle and operating cycle, respectively, and $D H I_{\text {dirunal }}$ and DHI $I_{\text {operating }}$ are the direct horizontal irradiance integrated over a diurnal cycle and operating 
cycle, respectively. By collecting the produced $\mathrm{H}_{2}(\mathrm{~g})$ at night, $\eta_{\text {diurnal }}=3.7 \%$ and $\eta_{\text {operating }}=$ $5.8 \%$ were obtained. PV modules with higher conversion efficiencies can further improve the overall efficiency of this hybrid device, provided that the operating voltage of the module is $\sim 2.2$ $2.3 \mathrm{~V}$, to maintain the desired cathode operating potential.

While the demonstration unit contained two discreet components: a PV cell and an electrochemical reactor with the dark electrodes operating at current densities relevant to the solar photon flux, a fully integrated hybrid device can be envisioned and constructed using many of the design principles in integrated PEC water-splitting reactors. ${ }^{38-39}$ The further development and potential deployment of such hybrid devices will likely primarily be in distributed applications and in places where electric grids and electrical transmission are not available. In the distributed applications, the operating current density of the catalysts and dark electrodes will be $\sim 10 \mathrm{~mA} \mathrm{~cm}^{-2}$ as driven by unconcentrated sunlight, hence the system described herein captures the key performance metrics and characteristics of such a device. In addition, the $\mathrm{Mo}_{2} \mathrm{C}$ powder used in this study could be replaced with high surface area, porous medium to eliminate the filtering process, and the required catalyst loading for the discharging process is relatively low for scalability of this concept. For instance, without any optimization of the $\mathrm{Mo}_{2} \mathrm{C}$ loading, to completely discharge the vanadium electrolyte from a relatively large photoactive device $\left(100 \mathrm{~cm}^{2}\right.$ active area, $10 \% \mathrm{STH}$ conversion efficiency, $7 \mathrm{kWh} / \mathrm{m}^{2} /$ day solar insolation) under operation during the day, only $5 \mathrm{~g}$ of $\mathrm{Mo}_{2} \mathrm{C}$ catalyst will be needed to generate the hydrogen within 30 minutes during the night. 
In summary, a proof-of-concept, hybrid solar-driven water-splitting device was demonstrated that produces $\mathrm{O}_{2}(\mathrm{~g})$ in the daylight and produces $\mathrm{H}_{2}(\mathrm{~g})$ on demand at an elevated pressure. Instead of transporting high pressure $\mathrm{H}_{2}$ over a large area in a traditional solar-driven water-splitting device that produces $\mathrm{H}_{2}$ and $\mathrm{O}_{2}$ simultaneously under illumination, the bipolar membrane-based hybrid device stores the renewable electrons and protons temporarily (daily, weekly or even seasonally) in the liquid form, e.g., vanadium-based redox couples, which can be transported readily into a centralized reactor for production of $\mathrm{H}_{2}$ as desired. The "solar-charged" vanadium redox couples could also be used in parallel with short-term electricity storage in the grid or longer-term fuel production in conjunction with further reduction reactions, including $\mathrm{CO}_{2}$ reduction or biomass upgrades. The approach is complementary to other approaches that are being developed to decouple the production of $\mathrm{H}_{2}(\mathrm{~g})$ and $\mathrm{O}_{2}(\mathrm{~g})$ in a water-splitting process, each of which has unique advantages and disadvantages from a complexity, cost and safety perspective in laboratory-sized demonstration systems in their use of simple vs. bipolar membranes, single vs. dual electrochemical cells, earth-abundant vs. precious metal electrocatalysts, etc. The hybrid device described herein thus provides additional possible design spaces for implementation of a hydrogen-based "solar refinery". 


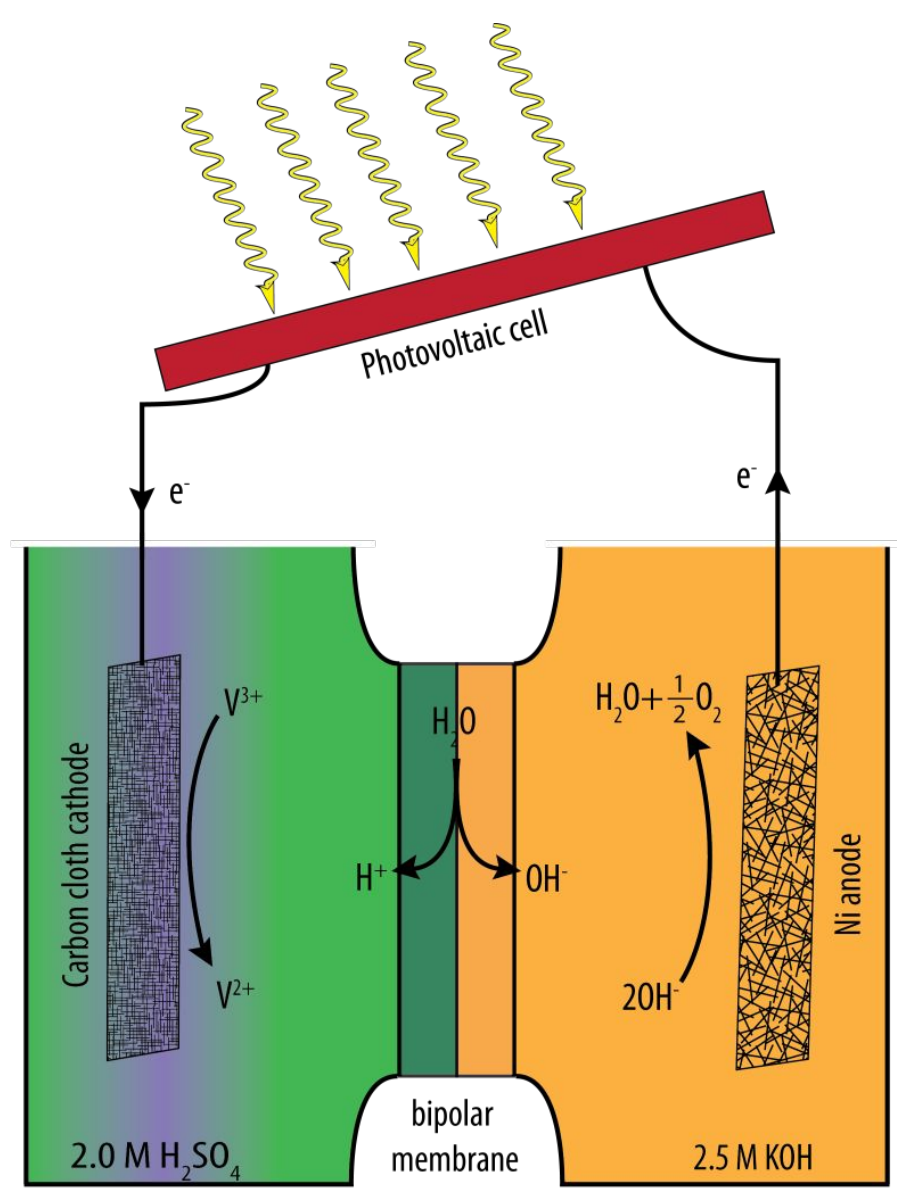

Figure 1. Schematic illustration of a solar-driven $\mathrm{V}^{3+/ 2+}\left(\mathrm{aq}, \mathrm{H}_{2} \mathrm{SO}_{4}\right) \mid \mathrm{KOH}(\mathrm{aq})$ cell in which a photovoltaic module generates energetic electrons and holes, a carbon cloth cathode effects vanadium reduction in $2.0 \mathrm{M} \mathrm{H}_{2} \mathrm{SO}_{4}(\mathrm{aq})$, a Ni mesh anode oxidizes water to $\mathrm{O}_{2}(\mathrm{~g})$ in $2.5 \mathrm{M}$ $\mathrm{KOH}(\mathrm{aq})$, and a bipolar membrane sustains the $\mathrm{pH}$ differential between the cathode and anode chambers. 

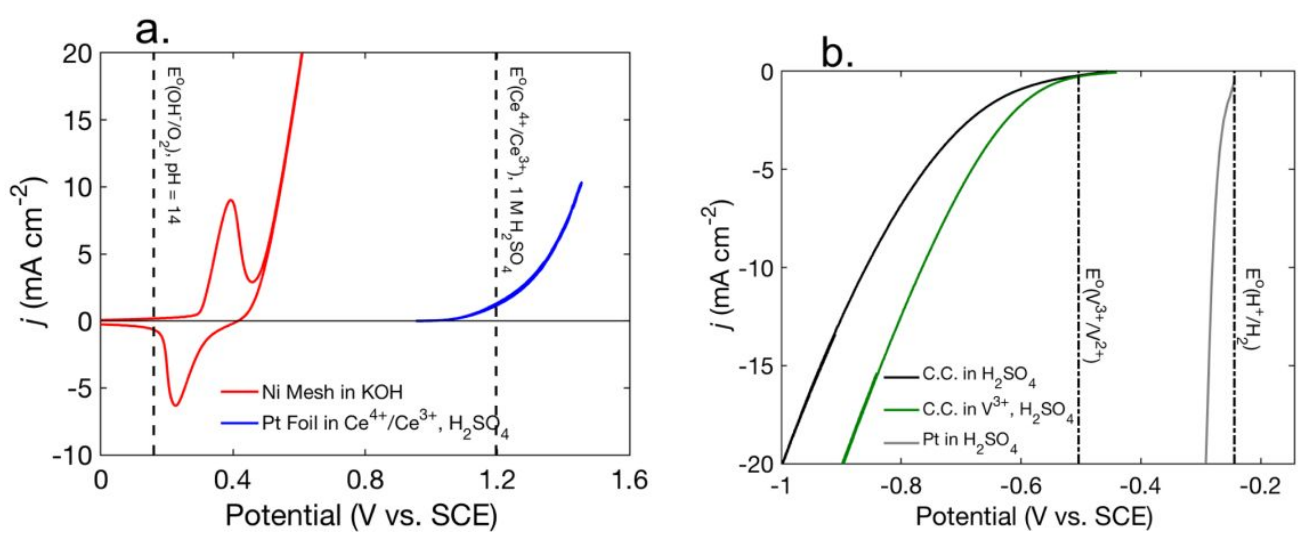

C.
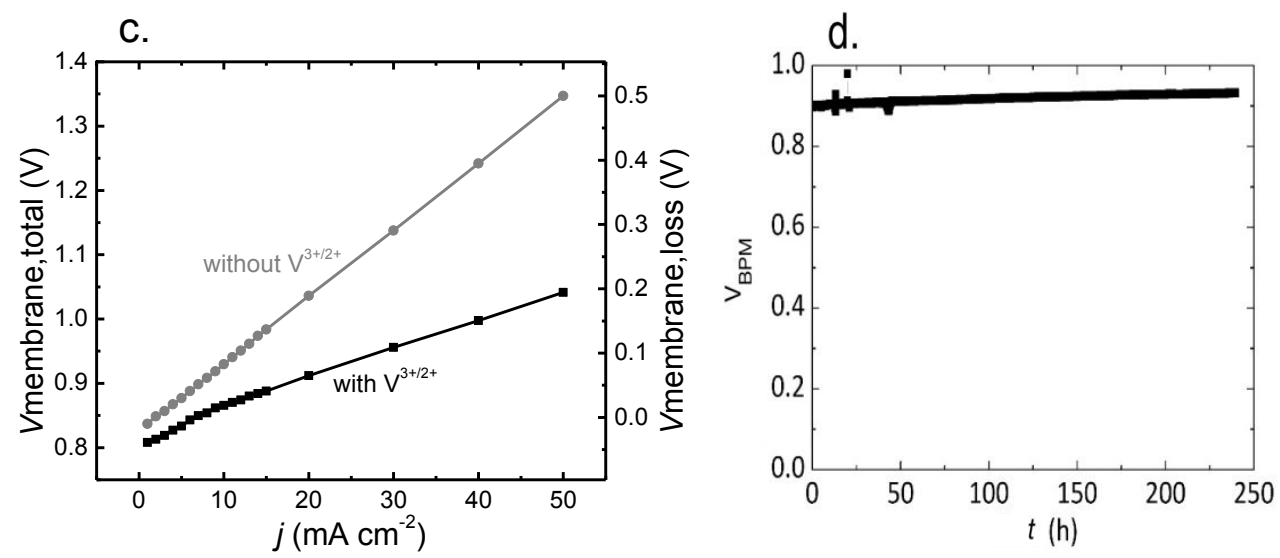

Figure 2. (a) Voltammetry of a Ni mesh $\left(6.0 \mathrm{~cm}^{2}\right.$ geometric area) in $2.5 \mathrm{M} \mathrm{KOH}(\mathrm{aq})$ (red) and Pt foil $\left(0.12 \mathrm{~cm}^{2}\right.$ area) in $\mathrm{Ce}^{4+} / \mathrm{Ce}^{3+}, 1.0 \mathrm{M} \mathrm{H}_{2} \mathrm{SO}_{4}$ (aq) (blue). (b) Voltammetry of a carbon cloth in $2.0 \mathrm{M} \mathrm{H}_{2} \mathrm{SO}_{4}$ (black) as well as of carbon cloth $\left(6.0 \mathrm{~cm}^{2}\right.$ geometric area) in $0.36 \mathrm{M} \mathrm{V}^{3+}, 2.0 \mathrm{M}$ $\mathrm{H}_{2} \mathrm{SO}_{4}(\mathrm{aq})$ (green). For comparison, voltammetry of $\mathrm{Pt}$ in $1.0 \mathrm{M} \mathrm{H}_{2} \mathrm{SO}_{4}$ (aq) (grey) is shown. ${ }^{40-41}$ (c) Measured membrane voltage, and voltage loss with (black squares) and without (grey circles) the presence of vanadium species, as a function of the current density normalized to the bipolar membrane. The cell configuration was $2.0 \mathrm{M} \mathrm{H}_{2} \mathrm{SO}_{4}(\mathrm{aq})(\mathrm{pH}=-0.16)$ with or without $\mathrm{V}^{3+}$ $/ \mathrm{V}^{2+} / \mathrm{BPM} / \mathrm{KOH}(\mathrm{aq})(\mathrm{pH}=14.21)$. (d) Bipolar membrane voltage as a function of time, with the current density across the bipolar membrane maintained at $10 \mathrm{~mA} \mathrm{~cm}{ }^{-2}$. The BPM, cathode and anode each had a geometric surface area of $6.0 \mathrm{~cm}^{2}$. 

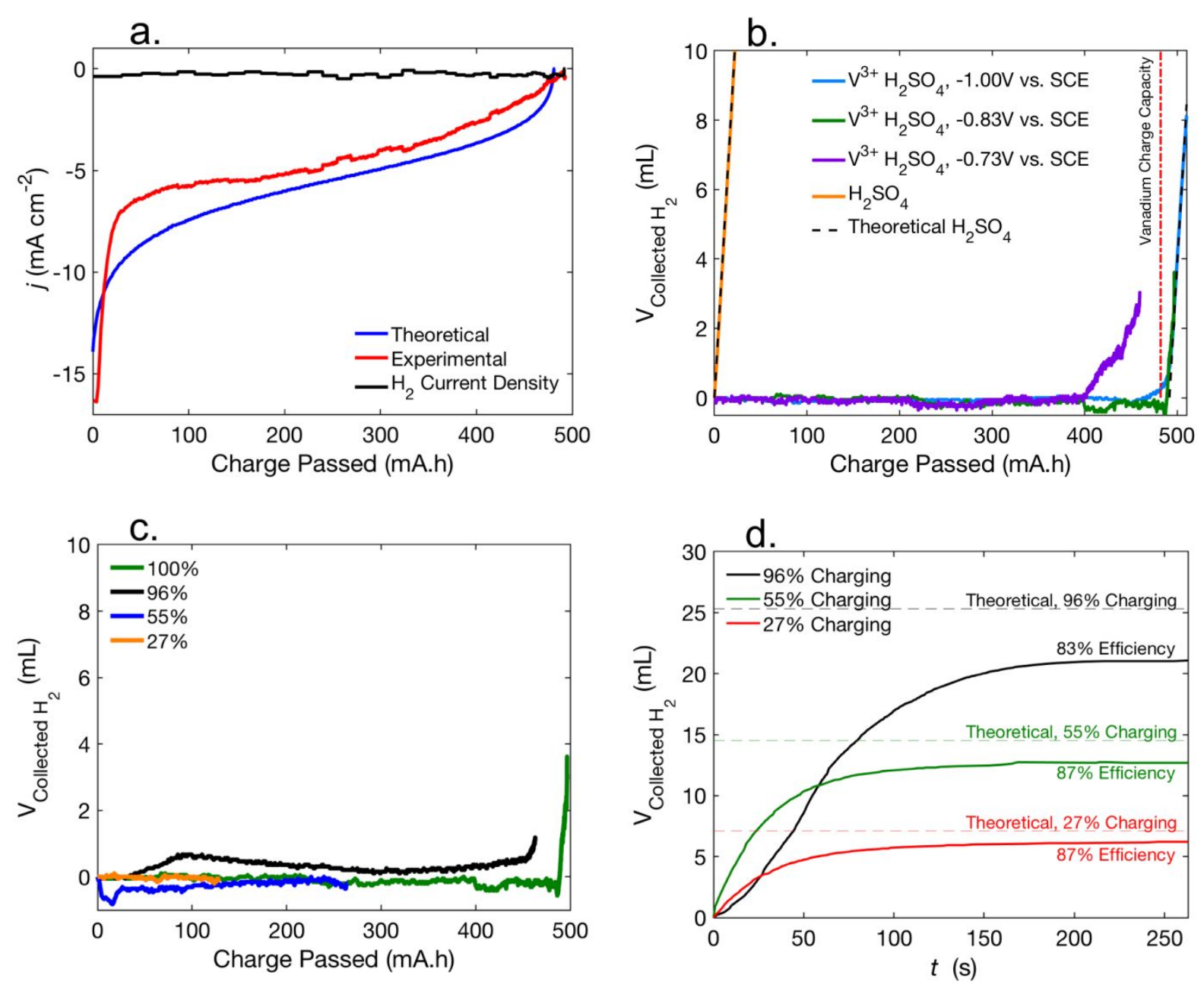

Figure 3. (a) Partial current density for the reduction of $0.36 \mathrm{M} \mathrm{V}^{3+}$ in $2.0 \mathrm{M} \mathrm{H}_{2} \mathrm{SO}_{4}$ (aq) at -830 $\mathrm{mV}$ (vs. SCE) (red), partial current density for production of $\mathrm{H}_{2}(\mathrm{~g})$ (black), and the theoretical current density determined by the Nernst equation, accounting for the $10 \mathrm{~mA}-\mathrm{h}$ passed to the solution during the voltammetry (blue). (b) Measured $\mathrm{H}_{2}(\mathrm{~g})$ collection during cell operation for 2.0 $\mathrm{M} \mathrm{H}_{2} \mathrm{SO}_{4}$ (aq) (orange), $0.36 \mathrm{M} \mathrm{V}^{3+}$ in $2.0 \mathrm{M} \mathrm{H}_{2} \mathrm{SO}_{4}$ (aq) at $-1.00 \mathrm{~V}$ (blue), $-0.830 \mathrm{~V}$ (green), and $-0.73 \mathrm{~V}$ (purple) vs. SCE, respectively. The dotted black line shows the expected $\mathrm{H}_{2}$ production volume in $2.0 \mathrm{M} \mathrm{H}_{2} \mathrm{SO}_{4}$ in the absence of vanadium species. (c) Hydrogen produced during runs of varying charge capacities at $-830 \mathrm{mV}$ vs. SCE. (d) Measured $\mathrm{H}_{2}(\mathrm{~g})$ collection during reaction 
of $6.0 \mathrm{~mL}$ of partially reduced $0.36 \mathrm{M} \mathrm{V}^{2+}, 2.0 \mathrm{M} \mathrm{H}_{2} \mathrm{SO}_{4}$ in the presence of the $\mathrm{Mo}_{2} \mathrm{C}$ catalyst. 

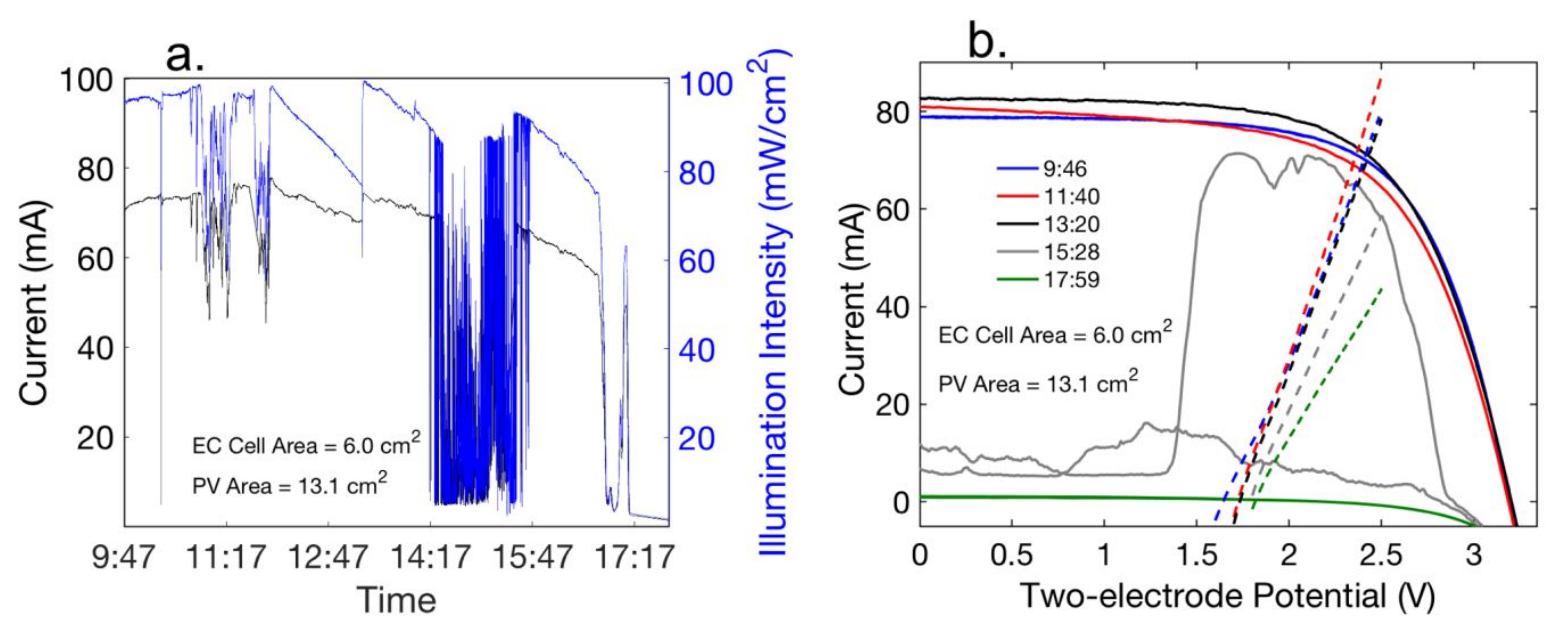

Figure 4. Outdoor measurements. (a) Current of the $\mathrm{V}^{3+/ 2+}\left(\mathrm{aq}, \mathrm{H}_{2} \mathrm{SO}_{4}\right) \mid \mathrm{KOH}(\mathrm{aq})$ cell coupled to a photovoltaic module (black), with the illumination intensity during cell operation measured by a photodiode (blue). (b) Overall polarization behavior for the photovoltaic module (solid lines) and for the $\mathrm{V}^{3+/ 2+}\left(\mathrm{aq}, \mathrm{H}_{2} \mathrm{SO}_{4}\right) \mid \mathrm{KOH}(\mathrm{aq})$ cell (dashed lines) during charging at times in the day. 


\section{ACKNOWLEDGMENT}

This material is based upon work performed by the Joint Center for Artificial Photosynthesis, a DOE Energy Innovation Hub, supported through the Office of Science of the U.S. Department of Energy under Award Number DE-SC0004993, as well as the Gordon and Betty Moore Foundation. The authors thank Caltech's SURF Board for a Summer Undergraduate Research Fellowship and acknowledge Caltech's Federal Work-Study program.

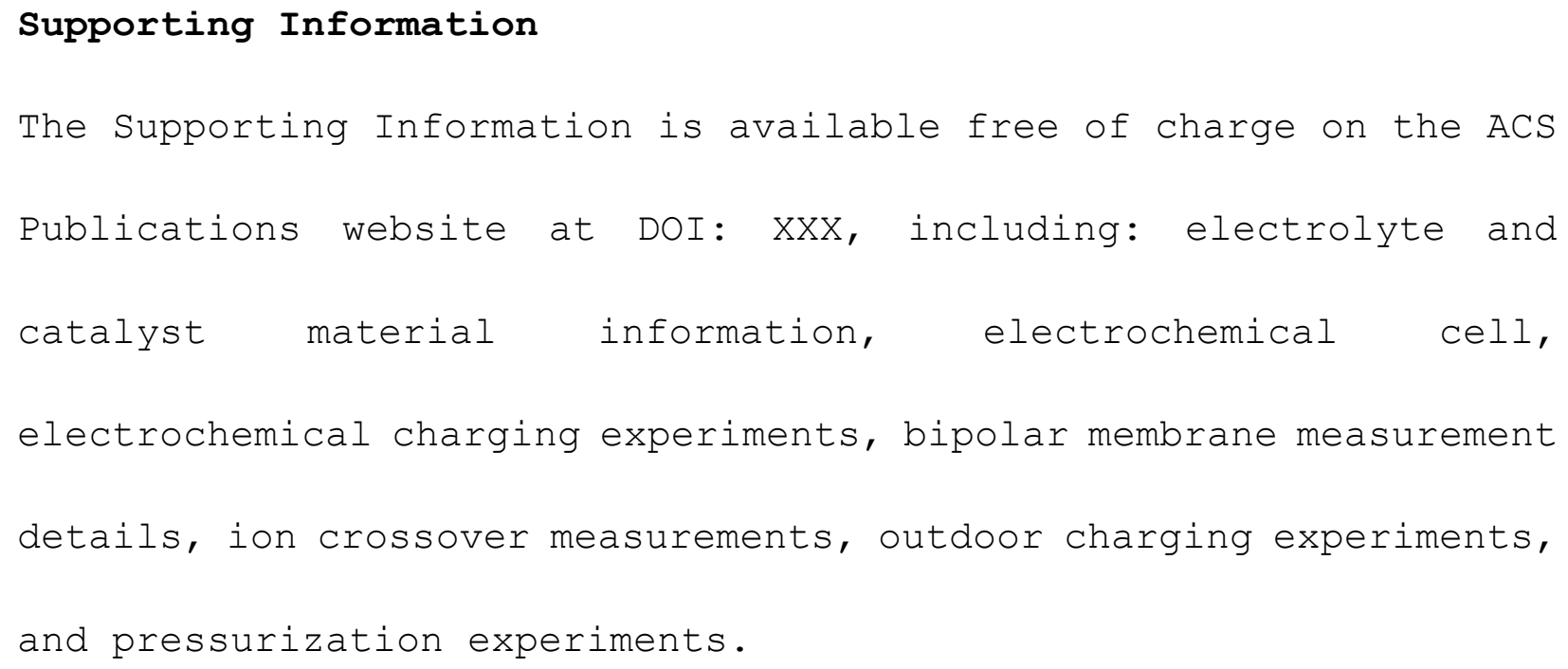




\section{REFERENCES}

(1) Haynes, W. M.; Lide, D. R.; Bruno, T. J., Crc Handbook of Chemistry and Physics: A ReadyReference Book OfChemical and Physical Data. CRC Press, Taylor \& Francis Group: Boca Raton, Florida, USA, 2015.

(2) Verlage, E.; Hu, S.; Liu, R.; Jones, R. J. R.; Sun, K.; Xiang, C.; Lewis, N. S.; Atwater, H. A. A Monolithically Integrated, Intrinsically Safe, 10\% Efficient, Solar-Driven Water-Splitting System Based on Active, Stable Earth-Abundant Electrocatalysts in Conjunction with Tandem IiiV Light Absorbers Protected By Amorphous $\mathrm{TiO}_{2}$ Films. Energy \& Environ. Sci. 2015, 8 (11), 3166-3172.

(3) Sun, K.; Liu, R.; Chen, Y.; Verlage, E.; Lewis, N. S.; Xiang, C. A Stabilized, Intrinsically Safe, 10\% Efficient, Solar-Driven Water-Splitting Cell Incorporating Earth-Abundant Electrocatalysts with Steady-State $\mathrm{pH}$ Gradients and Product Separation Enabled by a Bipolar Membrane. Adv. Energy Mater. 2016, 6 (13), 1600379.

(4) Luo, J.; Vermaas, D. A.; Bi, D.; Hagfeldt, A.; Smith, W. A.; Grätzel, M. Bipolar MembraneAssisted Solar Water Splitting in Optimal pH. Adv. Energy Mater. 2016, 6.

(5) Luo, J.; Im, J.-H.; Mayer, M. T.; Schreier, M.; Nazeeruddin, M. K.; Park, N.-G.; Tilley, S. D.; Fan, H. J.; Grätzel, M. Water Photolysis at 12.3\% Efficiency via Perovskite Photovoltaics and Earth-Abundant Catalysts. Science 2014, 345 (6204), 1593-1596.

(6) Wrighton, M. S.; Ellis, A. B.; Wolczanski, P. T.; Morse, D. L.; Abrahamson, H. B.; Ginley, D. S. Strontium Titanate Photoelectrodes. Efficient Photoassisted Electrolysis of Water at Zero Applied Potential. J. Am. Chem. Soc. 1976, 98 (10), 2774-2779. 
(7) Najjar, Y. S. H. Hydrogen Safety: The Road toward Green Technology. Int. J. Hydrogen Energy 2013, 38 (25), 10716-10728.

(8) Jin, J.; Walczak, K.; Singh, M. R.; Karp, C.; Lewis, N. S.; Xiang, C. An Experimental and Modeling/Simulation-Based Evaluation of the Efficiency and Operational Performance Characteristics of an Integrated, Membrane-Free, Neutral $\mathrm{pH}$ Solar-Driven Water-Splitting System. Energy \& Environ. Sci. 2014, 7 (10), 3371-3380.

(9) Hashemi, S. M. H.; A. Modestino, M.; Psaltis, D. A Membrane-less Electrolyzer for Hydrogen Production across the pH Scale. Energy \& Environ. Sci. 2015, 8 (7), 2003-2009.

(10) Hashemi, S. M. H.; Neuenschwander, M.; Hadikhani, P.; Modestino, M. A.; Psaltis, D. Membrane-less Micro Fuel Cell Based on Two-Phase Flow. J. Power Sources 2017, 348, 212218.

(11) Rohland, B.; Eberle, K.; Ströbel, R.; Scholta, J.; Garche, J. Electrochemical Hydrogen Compressor. Electrochim. Acta 1998, 43 (24), 3841-3846.

(12) Ströbel, R.; Oszcipok, M.; Fasil, M.; Rohland, B.; Jörissen, L.; Garche, J. The Compression of Hydrogen in an Electrochemical Cell Based on a Pe Fuel Cell Design. J. Power Sources 2002, 105 (2), 208-215.

(13) Collier, A.; Wang, H.; Zi Yuan, X.; Zhang, J.; Wilkinson, D. P. Degradation of Polymer Electrolyte Membranes. Int. J. Hydrogen Energy 2006, 31 (13), 1838-1854.

(14) Tang, H.; Peikang, S.; Jiang, S. P.; Wang, F.; Pan, M. A Degradation Study of Nafion Proton Exchange Membrane of Pem Fuel Cells. J. Power Sources 2007, 170 (1), 85-92.

(15) Chen, L.; Dong, X.; Wang, Y.; Xia, Y. Separating Hydrogen and Oxygen Evolution in 
Alkaline Water Electrolysis Using Nickel Hydroxide. Nat. Commun. 2016, 7, 11741.

(16) Landman, A.; Dotan, H.; Shter, G. E.; Wullenkord, M.; Houaijia, A.; Maljusch, A.;

Grader, G. S.; Rothschild, A. Photoelectrochemical Water Splitting in Separate Oxygen and Hydrogen Cells. Nat. Mater. 2017, 16, 646-651.

(17) Ma, Y. Y.; Dong, X. L.; Wang, Y. G.; Xia, Y. Y. Decoupling Hydrogen and Oxygen Production in Acidic Water Electrolysis Using a Polytriphenylamine-Based Battery Electrode. Angew. Chem. Int. Ed. 2018, 57 (11), 2904-2908.

(18) Bloor, L. G.; Solarska, R.; Bienkowski, K.; Kulesza, P. J.; Augustynski, J.; Symes, M. D.; Cronin, L. Solar-Driven Water Oxidation and Decoupled Hydrogen Production Mediated by an Electron-Coupled-Proton Buffer. J. Am. Chem. Soc. 2016, 138 (21), 6707-6710.

(19) Symes, M. D.; Cronin, L. Decoupling Hydrogen and Oxygen Evolution during Electrolytic Water Splitting Using an Electron-Coupled-Proton Buffer. Nat. Chem. 2013, 5 (5), 403-409.

(20) Rausch, B.; Symes, M. D.; Chisholm, G.; Cronin, L. Decoupled Catalytic Hydrogen Evolution from a Molecular Metal Oxide Redox Mediator in Water Splitting. Science 2014, 345 (6202), 1326-1330.

(21) Amstutz, V.; Toghill, K. E.; Powlesland, F.; Vrubel, H.; Comninellis, C.; Hu, X. L.; Girault, H. H. Renewable Hydrogen Generation from a Dual-Circuit Redox Flow Battery. Energy \& Environ. Sci. 2014, 7 (7), 2350-2358.

(22) McCrory, C. C. L.; Jung, S.; Ferrer, I. M.; Chatman, S. M.; Peters, J. C.; Jaramillo, T. F. Benchmarking Hydrogen Evolving Reaction and Oxygen Evolving Reaction Electrocatalysts for 
Solar Water Splitting Devices. J. Am. Chem. Soc. 2015, 137 (13), 4347-4357.

(23) McCrory, C. C. L.; Jung, S.; Peters, J. C.; Jaramillo, T. F. Benchmarking Heterogeneous Electrocatalysts for the Oxygen Evolution Reaction. J. Am. Chem. Soc. 2013, 135 (45), 1697716987.

(24) Sun, K.; Saadi, F. H.; Lichterman, M. F.; Hale, W. G.; Wang, H.-P.; Zhou, X.; Plymale, N. T.; Omelchenko, S. T.; He, J.-H.; Papadantonakis, K. M., et al. Stable Solar-Driven Oxidation of Water by Semiconducting Photoanodes Protected by Transparent Catalytic Nickel Oxide Films. Proc. Natl. Acad. Sci. U.S.A. 2015, 112 (12), 3612-3617.

(25) Sun, K.; McDowell, M. T.; Nielander, A. C.; Hu, S.; Shaner, M. R.; Yang, F.; Brunschwig, B. S.; Lewis, N. S. Stable Solar-Driven Water Oxidation to $\mathrm{O}_{2}(\mathrm{~g})$ by Ni-Oxide-Coated Silicon Photoanodes. J. Phys. Chem. Lett. 2015, 6 (4), 592-598.

(26) Zhou, X.; Liu, R.; Sun, K.; Friedrich, D.; McDowell, M. T.; Yang, F.; Omelchenko, S. T.; Saadi, F. H.; Nielander, A. C.; Yalamanchili, S., et al. Interface Engineering of the Photoelectrochemical Performance of Ni-Oxide-Coated n-Si Photoanodes by Atomic-Layer Deposition of Ultrathin Films of Cobalt Oxide. Energy \& Environ. Sci. 2015, 8 (9), 2644-2649.

(27) Kenney, M. J.; Gong, M.; Li, Y.; Wu, J. Z.; Feng, J.; Lanza, M.; Dai, H. HighPerformance Silicon Photoanodes Passivated with Ultrathin Nickel Films for Water Oxidation. Science 2013, 342 (6160), 836-40.

(28) Walter, M. G.; Warren, E. L.; McKone, J. R.; Boettcher, S. W.; Mi, Q.; Santori, E. A.; Lewis, N. S. Solar Water Splitting Cells. Chem. Rev. 2010, 110 (11), 6446-6473.

(29) Jiang, C.; Moniz, S. J. A.; Wang, A.; Zhang, T.; Tang, J. Photoelectrochemical Devices 
for Solar Water Splitting - Materials and Challenges. Chem. Soc. Rev. 2017, 46 (15), 4645-4660.

(30) Sivula, K.; van de Krol, R. Semiconducting Materials for Photoelectrochemical Energy Conversion. Nat. Rev. Mater. 2016, 1, 15010.

(31) Heller, A.; Miller, B.; Thiel, F. A. 11.5\% Solar Conversion Efficiency in the Photocathodically Protected $p$-Inp/ $\mathrm{V}^{3+}-\mathrm{V}^{2+}-\mathrm{HCl} / \mathrm{C}$ Semiconductor Liquid Junction Cell. Appl. Phys. Lett. 1981, $38(4), 282-284$.

(32) Reiter, R. S.; White, W.; Ardo, S. Communication-Electrochemical Characterization of Commercial Bipolar Membranes under Electrolyte Conditions Relevant to Solar Fuels Technologies. J. Electrochem. Soc. 2016, 163 (4), H3132-H3134.

(33) Vermaas, D. A.; Wiegman, S.; Nagaki, T.; Smith, W. A. Ion Transport Mechanisms in Bipolar Membranes for (Photo)electrochemical Water Splitting. Sustainable Energy Fuels 2018, $2(9), 2006-2015$.

(34) Vargas-Barbosa, N. M.; Geise, G. M.; Hickner, M. A.; Mallouk, T. E. Assessing the Utility of Bipolar Membranes for use in Photoelectrochemical Water-Splitting Cells. ChemSusChem 2014, 7 (11), 3017-3020.

(35) Zhou, X.; Liu, R.; Sun, K.; Chen, Y.; Verlage, E.; Francis, S. A.; Lewis, N. S.; Xiang, C. Solar-Driven Reduction Of 1 atm of $\mathrm{CO}_{2}$ to Formate at 10\% Energy-Conversion Efficiency by Use of a $\mathrm{TiO}_{2}$-Protected III-V Tandem Photoanode in Conjunction with a Bipolar Membrane and a Pd/C Cathode. ACS Energy Lett. 2016, 1 (4), 764-770.

(36) Yan, Z.; Zhu, L.; Li, Y. C.; Wycisk, R. J.; Pintauro, P. N.; Hickner, M. A.; Mallouk, T. E. The Balance of Electric Field and Interfacial Catalysis in Promoting Water Dissociation in 
Bipolar Membranes. Energy \& Environ. Sci. 2018, 11 (8), 2235-2245.

(37) Vermaas, D. A.; Sassenburg, M.; Smith, W. A. Photo-Assisted Water Splitting with Bipolar Membrane Induced pH Gradients for Practical Solar Fuel Devices. Journal of Materials Chemistry A 2015, 3 (38), 19556-19562.

(38) Haussener, S.; Xiang, C. X.; Spurgeon, J. M.; Ardo, S.; Lewis, N. S.; Weber, A. Z. Modeling, Simulation, and Design Criteria for Photoelectrochemical Water-Splitting Systems. Energy \& Environ. Sci. 2012, 5 (12), 9922-9935.

(39) Xiang, C.; Weber, A. Z.; Ardo, S.; Berger, A.; Chen, Y.; Coridan, R.; Fountaine, K. T.; Haussener, S.; Hu, S.; Liu, R., et al. Modeling, Simulation, and Implementation of Solar-Driven Water-Splitting Devices. Angew. Chem. Int. Ed. 2016, 55 (42), 12974-12988.

(40) Saadi, F. H.; Carim, A. I.; Drisdell, W. S.; Gul, S.; Baricuatro, J. H.; Yano, J.; Soriaga, M. P.; Lewis, N. S. Operando Spectroscopic Analysis of Cop Films Electrocatalyzing the Hydrogen-Evolution Reaction. J. Am. Chem. Soc. 2017, 139 (37), 12927-12930.

(41) Saadi, F. H.; Carim, A. I.; Verlage, E.; Hemminger, J. C.; Lewis, N. S.; Soriaga, M. P. Cop as an Acid-Stable Active Electrocatalyst for the Hydrogen-Evolution Reaction: Electrochemical Synthesis, Interfacial Characterization and Performance Evaluation. J. Phys. Chem. C 2014, 118 (50), 29294-29300. 